\title{
COLLECTION AND MARKETING OF NON-TIMBER FOREST PRODUCTS BY CHEPANG COMMUNITY IN NEPAL
}

\author{
Luni Piya MSc $(\mathrm{Ag})^{1}$, K.L. Maharjan $\mathrm{PhD}^{2}$, N.P. Joshi MSc $(\mathrm{Ag})^{3}$ and D.R. Dangol PhD ${ }^{*}$
}

\begin{abstract}
Chepangs are highly marginalized indigenous nationalities of Nepal, who live nearby the forests that are rich in Non-timber Forest Products (NTFPs) of commercial importance. These NTFPs can be a potential source of income for Chepangs. This study describes the role of Chepangs in the marketing channel of those NTFPs and analyses the household socio-economic characteristics that influence the collection and marketing of NTFPs by Chepangs in Shaktikhor VDC of Chitwan district using backward multiple regression method. Empirical evidences show that collection and marketing of NTFPs is not an attractive source of income especially for those relatively better-off Chepang households who possess higher landholdings, food self-sufficiency, and income from other alternative sources. This is because the current price offered for the NTFPs collected by the community is very nominal, that do not even cover the labour costs involved. Praja Cooperative Limited (PCL), a Chepang community based institution in Shaktikhor, is struggling to provide better prices for Chepangs. However, it is facing challenges due to limited institutional management capacity of Chepangs. Further empowerment of PCL Can contribute to improve the bargaining power of Chepang community in NTFP trade.
\end{abstract}

Key Words: backward multiple regression, household socio-economic characteristics, indigenous nationalities, marketing channel, Praja Cooperative Limited

\section{INTRODUCTION}

Non-Timber Forest Products (NTFPs) are an important source of livelihoods for the rural populations all over the world. Rural communities depend on forest for fulfilling subsistence needs like food, fodder, litter, and fuel wood. Different studies done by different organizations reveal that a significant proportion of the world rural population is highly dependent upon forest resources. For instance, according to an estimate by World Commission of Forestry and Sustainable Development, 350 million depend almost entirely for their subsistence needs on forests, and another 1 billion depend on forests and trees for fuel wood, food, and fodder (WCFSD, 1999). Similarly, the World Bank (2001) reports that 1.6 billion depend to varying degrees on forest for their livelihoods, with 350 million living in or near dense forests depending on them to a high degree. In the same line, the Food and Agriculture Organization (FAO) estimates that 80 percent of the population in the developing countries relies on NTFPs for nutritional and health needs (FAO, 2003). Though the numbers estimated by different organizations may vary, these studies suggest that there is quite a significant proportion of population living in or nearby the forests and depending upon it to some degree. Forest products act as buffers during the times of hardships and are often used as safety nets where the rural community depends on these resources to bridge the hunger gaps (Neumann and Hirsh, 2000; Sills et al., 2003; Belcher, 2005; Maharjan and Khatri-Chhetri, 2006). NTFPs not only fulfil the subsistence needs of the rural population, but also contribute in generating cash-income. Many of these NTFPs have market demand, so they offer an opportunity to earn cash income especially in cash-

\footnotetext{
${ }^{1}$ PhD student, IDEC, Hiroshima Univ., Japan, Email: loonypiya@hotmail.com

${ }^{2}$ Professor, IDEC, Hiroshima Univ., Japan, Email: mkeshav@hiroshima-u.ac.jp

${ }^{3}$ PhD student, IDEC, Hiroshima Univ., Japan, Email: nirajpjoshi@hotmail.com

4 Prof., IAAS, TU, Nepal, visiting Prof., IDEC, Hiroshima Univ., Japan, Email: dharmadangol@hotmail.com
} 
constrained rural economies where alternative sources of cash-income generating employments are very limited. For example, indigenous tribes in Western Ghats of South India depend up to 50percent on NTFP as a source of income (Sadashivappa et al., 2006); in the Palawan Island of the Phillipines, collection of non-wood forest products is the most important livelihoods strategy of the Tagbanua tribe (Lacuna-Richman, 2004); production and marketing of NTFPs form a major source of rural income in the South West Province of Cameroon (Fuashi, 2005); and for many other countries in Africa (Chupezi et al., 2009).

Forests form an integral part of rural livelihoods in Nepal. Forest products not only provide the rural population with subsistence needs like fuel wood, fodder, and litter, but also provide wild foods during the periods of food shortage when the grain storage starts dwindling and the new harvest is not yet available (see Maharjan and Khatri-Chhetri, 2006, Piya et al., 2011a). Many NTFPs also have medicinal (Rijal, 2008) and socio-cultural values (Aryal, 2007). Besides these subsistence uses, trade of NTFPs form a source of cash income for many of the rural population in Nepal (Chhetri and Gupta, 2006; Edwards, 1996; Kunwar et al., 2009). Forests in hills and mountains of Nepal are home to many medicinal and aromatic plants. With commercialization of such plants and opening up of new markets, NTFPs have evolved as an important source of income for many rural communities in Nepal. These NTFPs are commonly gathered by local communities in the remote rural villages of Nepal and are sold to road-head businessmen and nearly 90 percent of which are exported to India in crude form, which is then supplied to other countries by the Indian wholesalers (Maraseni et al., 2006; Pandit, 2008; Thapa Magar, 2008).

The Chepangs, one of the indigenous nationalities ${ }^{1}$ living in the hills of central and western Nepal, are among many such rural communities in Nepal who are highly dependent upon forest resources for their subsistence livelihoods; and are involved in the collection and marketing of NTFPs for cash-income generation. Chepangs live in the difficult terrains in the hills of Chitwan, Makawanpur, Dhading, and Gorkha districts of Nepal. Hogdson (1874) stated that Chepangs lived a fully nomadic life, depending fully on forest resources for hunting and gathering. Nearly a century after Hodgson, a comprehensive study about Chepangs by Rai (1985) reported that though Chepangs still practiced a good deal of hunting and gathering, agriculture formed the mainstay of their livelihoods, and they practiced khoriya or shifting cultivation. However, their access to forest was severely restricted due to the introduction of new government policies, most notably the enactment of Private Forest Nationalization Act in $1957^{2}$. Restrictions on hunting, gathering, and clearing of forest patches for khoriya cultivation led to the transition of their livelihoods to sedentary agriculture. Currently, although agriculture forms the major source of their livelihoods, it is not sufficient to provide food for the whole year. Chepangs thus depend upon a diversified livelihoods strategy comprising of agriculture, livestock, wage labour, collection and sale of NTFPs, skilled and salaried jobs, handicrafts, and remittance (Piya et al., 2011b). Although Chepangs have come a long way from forest based hunting-gathering nomadism to

\footnotetext{
${ }^{1}$ According to National Foundation for Development of Indigenous Nationalities Act 2002, indigenous nationalities means tribes or communities having their own mother language and traditional rites and customs, distinct cultural identity, distinct social structure and written or unwritten history. Based on the same Act, Nepal Government has identified 59 indigenous nationalities that are further classified into five groups: endangered, highly marginalized, marginalized, disadvantaged, and advanced. The indigenous nationalities are further classified into Mountains, Hills, and Tarai based on the geographical location where they form a majority. Chepangs fall under hilly and highly marginalized indigenous nationalities, together with Baramu and Thami.

${ }^{2}$ Under the Private Forest Nationalization Act 1957, all the forests that had been used from the past under the traditional rights were included under the government ownership. This put a restriction in the hunting and gathering activities, thereby negatively affecting the traditional system of the Chepang livelihoods. Chepangs had no legal ownership of land where they practiced khoriya, and most of them remained as uncultivated patches within the forest area, which now came under the government ownership.
} 
sedentary agriculture, the contribution of forest resources to their livelihoods has remained significant. With the subsequent opening of NTFP markets, NTFP has evolved as an important source of cash income for the Chepang community.

There are several livelihoods related studies done in the Chepang community. A comprehensive study done by Gribnau et al. (1997) in Chitwan district reports that Chepang households obtain 7 percent of their cash income from forests. In another study by FORWARD (2001), it is reported that NTFPs form a source of cash income for 11 percent, 5 percent, and 3 percent of the sample households in Chitwan, Dhading, and Gorkha districts respectively. A recent study by Thapa Magar (2008) in Chitwan district shows that NTFPs contribute 18.14 percent of the total household income, and average income earned from NTFPs was higher for poor households compared to medium and rich households. Besides these, there are very few NTFP related studies that have been conducted in the areas where Chepang population form a majority (Maraseni et al., 2006; Pandit, 2008). Maraseni et al. (2006) focus on the distribution of profit margin along the value chain for two particular NTFPs, while Pandit (2008) focuses more on the NTFP collection and management practices under government and community forest management systems, and the impact of these practices on the status of forest and NTFPs. However, these studies do not focus exclusively on the Chepang community, thereby failing to discuss the characteristics of Chepang households that determine the extent to which those households depend on NTFPs as a source of livelihoods. Socio-economic factors are important for understanding the local dynamics that influence the harvesting and marketing of NTFPs at the household level. This study will contribute to the existing dearth of literatures by analysing how the socioeconomic status of a household determines the extent of their dependence on NTFPs for cash income. This paper will document the diversity of NTFPs collected and marketed by the Chepang community from one of the Village Development Committees (VDCs) in central Nepal. Secondly, this paper will identify various agents involved in the marketing channel of major NTFPs collected by the Chepang community in that VDC. Finally, this paper will analyse the socio-economic factors that influence the income generated from NTFP by the Chepang households.

\section{METHODOLOGY}

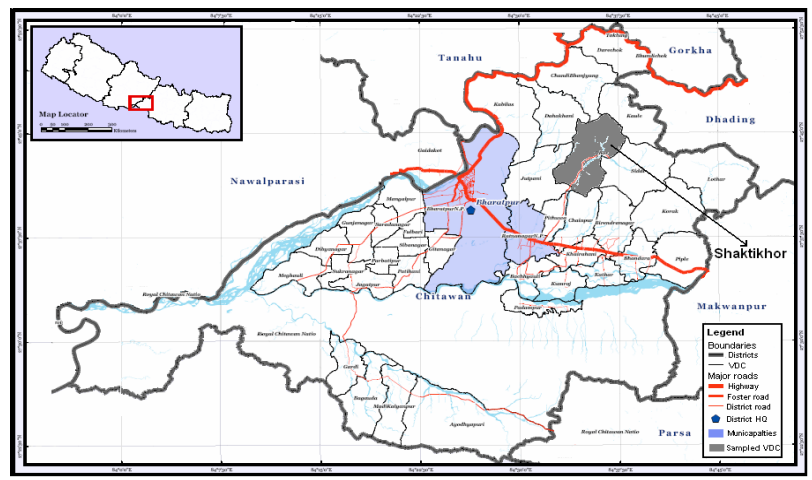

Fig.1: Map Showing the Study VDC

Source: http://www.un.org.np/maps/maps.php
This study was conducted in Shaktikhor VDC in Chitwan district of Nepal. Chepangs are the largest ethnic group in Shaktikhor VDC and they form 34.7 percent of the total population in the VDC. Shaktikhor VDC is linked to the East-West Highway by an all season graveled road up to the foothills of the VDC. Other adjoining hilly VDCs where Chepangs live (i.e. Siddhi, Korak, Kaule, and Lothar VDCs) are not connected by motorable roads (Fig. 1). Thus, Shaktikhor is the main market center of the

inhabitants of the adjoining VDCs. Elevation of Shaktikhor VDC varies from $250-1200$ meters above sea level (masl), however, for the purpose of collecting important NTFPs, Chepang community from this VDC often travel to the forests of adjoining VDCs located at higher elevations, the highest point being the Siraichuli, located in Kaule VDC, at an elevation of 1900 masl (Gribnau et al., 1997). The maximum species richness of medicinal 
and aromatic plants lies at an elevation of 1000 - 2000 masl (Kunwar and Bussman, 2008); thus, forests in and around Shaktikhor has a rich diversity of commercially important NTFPs.

Recognizing the potential of NTFP market in the area, Praja (Chepang) Cooperative Limited (PCL) was established in Shaktikhor bazaar in 1998; it received financial and technical supports from SNV for five years after which it was handed over to the Chepang community in 2003. PCL is currently owned and run solely by the Chepang community. PCL is registered in the District Cooperative Office of Chitwan district, and the Chepangs from Shaktikhor, Kaule, Korak and Siddhi VDC are the shareholders of PCL. It forms the collection center of NTFPs collected from Shaktikhor, Kaule, Korak, Siddhi, and Lothar VDCs. Besides PCL, many individual businessmen are involved in the trade of NTFPs in Shaktikhor bazaar. Thus, NTFP market is quite well established in Shaktikhor, and the dominance of Chepang community in the VDC is the main rationale for the purposive selection of Shaktikhor VDC as our study site.

Household survey was conducted to obtain information about the demographic and socioeconomic characteristics of the Chepang households, the diversity of NTFPs collected, and the income generated from these NTFPs. Sixty Chepang households were randomly selected for the purpose of household survey. It accounts for 15 percent of the total Chepang households in Shaktikhor VDC. Semi-structured interview schedules were used for the purpose of household survey, and self-administered interview was conducted with the members of the households. Field visits were made in three phases: the household survey was conducted in August-September 2008 and follow-up field visits were done in FebruaryMarch 2009 and February-March 2010. All the households covered by the survey are untouched by transportation facilities and electricity. In order to generate information about the marketing channel, key informants' interview was conducted with three local businessmen in Shaktikhor bazaar and the staffs of PCL involved in the trade of NTFPs with Chepangs.

A list of NTFPs collected for marketing was prepared for each household and income generated from the sale of those NTFPs were recorded. The unit price of those products was also recorded and it was later cross-checked during interview with the road-head businessmen in Shaktikhor bazaar. The marketing channel of major NTFPs traded from Shaktikhor bazaar was prepared based on the information generated from the household survey and interview with the road-head traders. The annual income of the households was also recorded by the respondents recalling the income from all the sources. Socio-economic factors affecting the actual harvesting and marketing activities of NTFPs differ spatially and are important in understanding the local dynamics (Neumann and Hirsch, 2000; Bista and Webb, 2006). To assess the factors determining the collection and sale of NTFPs by the households, a multiple linear backward regression analysis was performed with annual income generated from the sale of NTFPs as the dependent variable, and ten socioeconomic attributes of the households as independent variables. Predictive Analytics Software (PASW) was used to run the regression model.

\section{RESULTS AND DISCUSSIONS}

\section{COLLECTION AND MARKETING OF NTFPS}

NTFPs are collected by the households either for subsistence or commercial purposes. All Chepang households covered by the survey are dependent upon NTFPs for their livelihoods for the domestic purposes like fodder, fuel wood, litter, food, and medicine. However, discussion of the NTFPs used for subsistence purposes is beyond the scope of this paper. This study thus includes only the commercially traded NTFPs in the area.

Nearly 68 percent of the households covered by the study collected NTFPs for commercial purposes. Table 1 shows the list of the NTFP collected by the Chepangs and the quantity 
that was traded at Shaktikhor bazaar over the period of one year at the time of field survey. Altogether 23 types of NTFPs were collected and sold by the Chepang households in Shaktikhor VDC. In terms of trade volume, Kaulo, Chiuri butter, and Daar were the three NTFPs that were traded in highest quantities. Fruits was the most commonly traded plant parts (6 plants) followed by bark (5 plants). Besides fruits and bark, butter, vines, flowers, roots, young shoots, spikes, leaves, and exudates were also traded. These NTFPs were mostly traded for medicinal purposes (14 plants) and others were traded for various purposes like incense, cosmetics, spices, dyes, fibres, vegetables, and tea. Kurilo fetched the best price followed by honey, however, the total transaction in terms of trade volume for these products is quite low. Chiuri butter ranks second in terms of volume of trade and ranks third in terms of price implying that market demand for Chiuri butter is quite high and it forms an important source of cash income for the community nearby Shaktikhor VDC.

Table 1: Major NTFPs Traded in Shaktikhor VDC

\begin{tabular}{|c|c|c|c|c|c|c|}
\hline \multirow{2}{*}{ Scientific name } & \multirow{2}{*}{$\begin{array}{l}\text { Nepali } \\
\text { name }\end{array}$} & \multirow{2}{*}{ Part traded } & \multirow{2}{*}{ Purpose } & \multirow{2}{*}{$\begin{array}{l}\text { Quantity } \\
\text { (ton) * }\end{array}$} & \multicolumn{2}{|c|}{ Selling Price (NRs./kg) } \\
\hline & & & & & Collector & Middlemen1 \\
\hline Persea bombycina & Kaulo & Bark & Incense & 41.5 & 14.6 & 19.3 \\
\hline Bassia butyracea & Chiuri & Butter & $\begin{array}{l}\text { Medicine, } \\
\text { Cosmetics }\end{array}$ & 30.0 & 80 & 85 \\
\hline Boehmeria rugulosa & Daar & Bark & Incense & 22.0 & 12.1 & 16.5 \\
\hline Viscum articulatum & Harchul & Plant & Medicine & 17.5 & 16 & 18.5 \\
\hline Tinospora sinensis & Gurjo & Vine & Medicine & 5.1 & 11.5 & 15.0 \\
\hline Terminalia bellirica & Barro & Fruit & Medicine & 4.7 & 14.6 & 21.5 \\
\hline Terminalia chebula & Harro & Fruit & Medicine & 4.5 & 16.8 & 22.8 \\
\hline Phyllanthus emblica & Amala & Fruit & Medicine & 4.0 & 17.8 & 23.5 \\
\hline Sapindus mukorossi & Rittha & Fruit & Cosmetics & 3.5 & 22.9 & 35.0 \\
\hline Thalictrum foliolosum & Bajuri & Root & Medicine & 3.0 & 50.9 & 57.5 \\
\hline Thysanolaena maxima & Amriso & Spike & Broom & 3.0 & 15.0 & $\mathrm{n} / \mathrm{a}$ \\
\hline Myrica esculenta & Kaafal & Bark & Medicine & 2.0 & 14.0 & 16.5 \\
\hline Asparagus racemosus & Kurilo & Root & Medicine & 1.7 & 133.3 & 183.3 \\
\hline \multirow{2}{*}{ Cinnamomum tamala } & Dalchini & Bark & Spice, Medicine & 1.5 & 25.0 & 31.5 \\
\hline & Tejpaat & Leaf & Spice, Medicine & 1.2 & 19.3 & 24.3 \\
\hline Honey & - & - & Medicine & 1.0 & 130 & 175 \\
\hline Rubia manjith & Majito & Vine & Dye & 0.6 & 30.0 & 35.0 \\
\hline Shorea robusta & Saldhup & Exudate & Incense & 0.5 & $\mathrm{n} / \mathrm{a}$ & $\mathrm{n} / \mathrm{a}$ \\
\hline Zanthoxylum sp. & $\begin{array}{l}\text { Boke } \\
\text { timur }\end{array}$ & Fruit & Medicine & $\mathrm{n} / \mathrm{a}$ & $\mathrm{n} / \mathrm{a}$ & $\mathrm{n} / \mathrm{a}$ \\
\hline Girardinia diversifolia & Allo & Bark & Fiber & $\mathrm{n} / \mathrm{a}$ & $\mathrm{n} / \mathrm{a}$ & $\mathrm{n} / \mathrm{a}$ \\
\hline Bambusa nepalensis & Bans & Young shoot & Vegetable & $\mathrm{n} / \mathrm{a}$ & 15.0 & - \\
\hline Dryopteris cochleata & Niuro & Young shoot & Vegetable & $\mathrm{n} / \mathrm{a}$ & 10.7 & - \\
\hline Piper longum & Pipla & Fruit & Medicine & $\mathrm{n} / \mathrm{a}$ & 15.0 & $\mathrm{n} / \mathrm{a}$ \\
\hline Jasminum gracile & Chameli & Flower & Medicine, Tea & $\mathrm{n} / \mathrm{a}$ & $\mathrm{n} / \mathrm{a}$ & $\mathrm{n} / \mathrm{a}$ \\
\hline
\end{tabular}

* This is the quantity of the NTFP that was traded by the road-head businessmen in Shaktikhor bazaar over the last one year from the date of interview. Source: Field survey, 2008 
With fast commercialization of the NTFPs, unsustainable harvesting of few species is evident in the field. Destructive harvesting is a serious problem especially for those species whose bark and roots are traded. During the time of interview, the trade for the bark of Kaulo and Daar was at its peak (Table 1), the annual quantity of dried bark traded from Shaktikhor being 41.5 tonnes for Kaulo and 22 tonnes for Daar. The trees of all ages were debarked for sale, as a result during the authors' subsequent field visits; there were no mature Kaulo and Daar trees left in the forest. Thapa Magar (2008) also raises similar

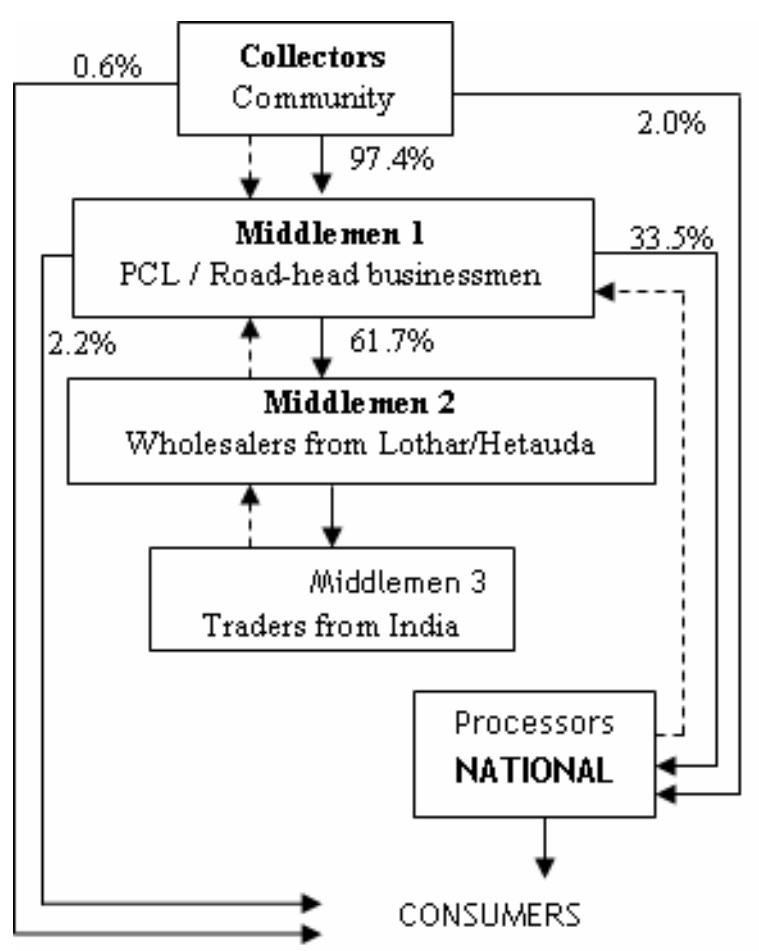

Note: Flow of products is shown by solid arrows and flow of agents is shown by dotted arrows. The numbers are proportion of total volume of NTFPs traded in that direction. concerns for the situation of Kaulo, especially in state-owned forests. Similar is the case for Kurilo and Bajuri whose roots are traded. For sustainable harvesting of barks, only branches of mature trees should be debarked from one side of the trunk, while allowing the younger trees to grow. Thapa Magar (2008) reports that destructive harvesting was done only in the state-owned forest, whereas in communitymanaged forests, the debarking was done only on one side of the trunk, without killing the whole tree. This suggests that although the collectors are aware of the consequences of destructive harvesting, it is not being followed. For preventing biodiversity degradation and resource depletion, PCL can play a role in formulating and maintaining rules and regulations for sustainable harvesting of such commercially important NTFPs in its working area. Also staffs of PCL can be trained as resource persons in the community, and mobilized to train the communities about the scientific way of harvesting the NTFPs.

Fig.2: Flow of products and agents in the NTFP marketing chain in Shaktikhor.

There are three different levels of middlemen involved in the NTFP trade in Shaktikhor (Fig.2). The collectors sell their products to PCL or road-head businessmen in Shaktikhor market. Besides PCL, there are three individual road-head businessmen in Shaktikhor who buys NTFPs from the collectors. Almost all the Chepang households are located in the hilly ridges of the VDC. Thus, they carry the NTFPs from their settlements to the road-head businessmen or PCL at the foot-hill of the VDC where the main market centre of Shaktikhor VDC is located. The price that the collectors receive from the road-head middlemen or PCL does not include the labour cost that is involved in collecting these NTFPs and carrying them down to the market. The next level of middlemen is the wholesalers from Lothar and Hetauda in Makawnapur district, who come to Shakikhor market to buy the NTFPs from the 
road-head businessmen in Shaktikhor, which is further sold to traders from India ${ }^{1}$. It was found that nearly 62 percent of the total volume of NTFP traded from Shaktikhor was exported in crude form to India; while only 35 percent of the NTFPs were bought by the national processors. The detail marketing channel showing the actors involved and the NTFPs traded along the route is shown in Fig. 3.

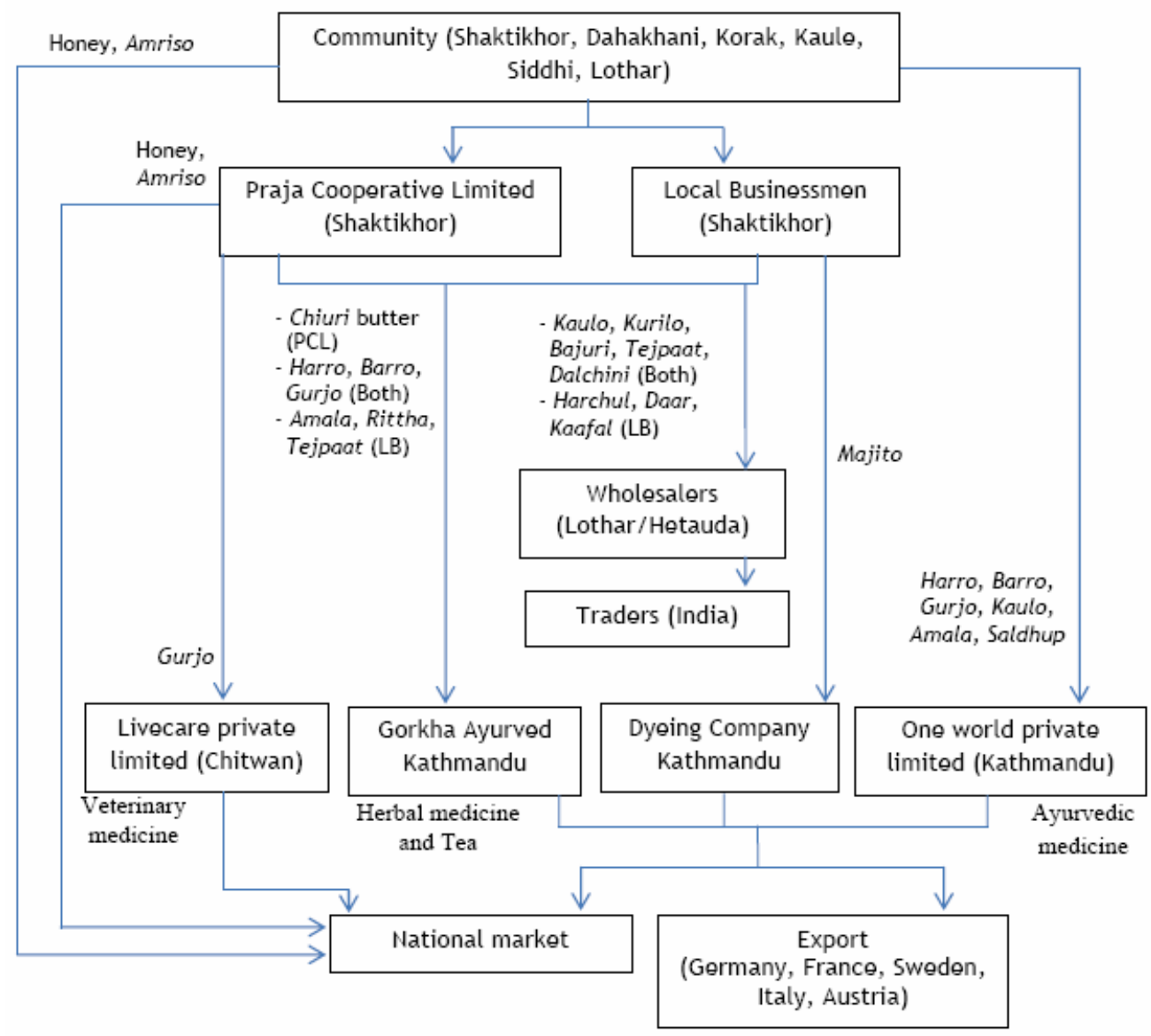

Fig.3: Detailed Marketing Channel of Major NTFPs Traded from Shaktikhor

The role of the Chepangs in the market chain was limited to collectors. No collectors had access to the middlemen outside the district. Except for PCL being an institution that is run by the Chepangs, all the road-head businessmen involved in the trade were non-Chepangs. Although PCL is an important community based institution for the Chepangs, it was found that only 30 percent of the total volume of NTFP in Shaktikhor was traded by PCL. There are two major business challenges that PCL has to face while competing with the local businessmen. Firstly, PCL lacks stock money that is needed to pay to the collectors while buying the NTFPs; collectors are reluctant to wait for their payments and would rather prefer to sell the NTFPs to the businessmen who give their payments immediately.

1 The marketing channel of the NTFPs after the Indian traders has not been discussed in this study because the NTFPs are taken by these traders across the national border to India. Discussion of the marketing channel outside Nepal is beyond the scope of this study. 
Secondly, Chepangs have to depend upon businessmen for loan during the emergency periods. During food shortages, Chepangs borrow food and cash from these businessmen which they pay back in terms of NTFPs. Thus, the relationship between the Chepang community and the road-head businessmen is not only that of a buyer-seller but it also acts as social safety nets which the Chepangs cannot easily break. They, therefore, continue selling their NTFPs to these businessmen. Furthermore, Chepangs lack institutional and business management abilities, which hinder formulation of effective business plans for PCL.

There are several reasons why the role of Chepang community is limited to collectors. Firstly, NTFP traders need to obtain collection license from the District Forestry Office for collection of NTFP and pay tax to the government. Chepangs are mostly ignorant of the official procedures and are thus reluctant to obtain the license. Secondly, the NTFPs need to be collected in enough volumes before they can be sold to the wholesalers, for which the NTFP need to be stored properly. Chepangs lack the capital needed for initial investment in constructing store houses, and buying packaging materials. Thirdly, they do not have access to information related to market, and furthermore, limited communication facilities and geographical isolation of the Chepang settlements prevents them from establishing a network with other agents involved in the market chain.

NTFP related studies in the Chepang areas show that the collectors are the one who have the least profit margin in the value chain. In order to increase the share of profit of the collectors, a popular recommendation is to shorten the market channel to reduce the middlemen involved (Maraseni et al., 2006; Pandit, 2008). However, collectors are often the weakest actors in the NTFP market chain and thus have least bargaining positions because of which even if the collectors bypass the middlemen, they are not necessarily assured a higher profit margin. Collectors do not possess the necessary capitals to bear the risks associated with stockpiling of perishable NTFPs. As Chepangs lack the necessary knowledge, capital, risk-bearing abilities, or legal rights to be able to exploit market opportunities where they do exist, the road-head businessmen play an important role in creating income generating opportunities for the Chepangs. They bear the associated risks for stockpiling the NTFPs, and provide outlet for sale and thus play an important role in the maintenance of a robust NTFP market (Bista and Webb, 2006). Development interventions targeting the Chepangs should rather focus on the capacity building of the community. In case of Chepang community in Shaktikhor VDC, increasing the competitiveness of PCL in the NTFP trade would help to improve the bargaining power of the Chepang community. For this, the PCL should be provided with financial and technical support. Since it is solely owned by the Chepang community, if the profit margin of PCL can be increased, it automatically means more dividend share for the community.

\section{SOCIO-ECONOMIC FACTORS INFLUENCING THE INCOME GENERATED FROM NTFPS}

On an average, NTFPs contributed 13.2 percent to the total income of the households, ranging from 0 percent to a maximum of 60.3 percent. The income generated from NTFPs thus varied greatly across the sample households. To assess the factors determining the collection and sale of NTFPs by the households, a backward multiple regression analysis was performed with annual income generated from the sale of NTFPs as the dependent variable, and ten socio-economic attributes of the households as independent variables. The definition and the summary statistics of the variables included in the regression analysis are summarized in Table 2.

Using the backward multiple regression, a significant model emerged $(F 8,51=2.86, p=$ 0.01 , and $R$ square $=0.31$ ). Of the total ten variables examined, eight variables were included in the final model. The results of the regression are presented in Table 3. 
Table 2: Description and Summary Statistics of the Variables

\begin{tabular}{|c|c|c|c|c|c|c|}
\hline Variables & Unit & Description & Mean & Std. & Min. & Max. \\
\hline \multicolumn{7}{|l|}{ Dependent } \\
\hline annincntfp & $\begin{array}{l}\text { Nepali } \\
\text { Rupees }\end{array}$ & $\begin{array}{l}\text { Annual income earned by a } \\
\text { household the sale of NTFPs }\end{array}$ & 10,617 & 15,630 & 0 & 107,956 \\
\hline \multicolumn{7}{|l|}{ Independent } \\
\hline agehhh & Years & $\begin{array}{l}\text { Age of the household head } \\
(\mathrm{HHH})\end{array}$ & 41.5 & 13.5 & 17 & 70 \\
\hline sexhhh $^{\mathrm{a}}$ & - & $\begin{array}{l}\text { Sex of the } \mathrm{HHH} \text {; dummy } \\
\text { variable: } 1=\text { male, } 0=\text { otherwise }\end{array}$ & 0.93 & 0.3 & 0 & 1 \\
\hline eduhhh & Years & Education of the $\mathrm{HHH}$ & 1.2 & 2.1 & 0 & 9 \\
\hline econactpop & Person & $\begin{array}{l}\text { Number of economically active } \\
\text { population in the household }\end{array}$ & 4.3 & 1.9 & 1 & 8 \\
\hline paddyland & $\mathrm{Ha}$ & $\begin{array}{l}\text { Area of paddyland owned by a } \\
\text { household }\end{array}$ & 0.2 & 0.2 & 0 & 0.7 \\
\hline upland & $\mathrm{Ha}$ & $\begin{array}{l}\text { Area of upland owned by a } \\
\text { household }\end{array}$ & 0.6 & 0.6 & 0 & 2.6 \\
\hline khoriya & $\mathrm{Ha}$ & $\begin{array}{l}\text { Area of khoriya owned by a } \\
\text { household }\end{array}$ & 0.4 & 0.5 & 0 & 2.0 \\
\hline Isu & LSU $^{1}$ & Livestock holding & 7.8 & 6.4 & 1.7 & 44 \\
\hline foodsuff & Months & Food self-sufficiency & 7.6 & 2.1 & 2 & 12 \\
\hline incothers & $\begin{array}{l}\text { Nepali } \\
\text { Rupees }\end{array}$ & $\begin{array}{l}\text { Annual income from sources } \\
\text { other than the sale of NTFPs }\end{array}$ & 69,610 & 40,802 & 10,918 & 194,646 \\
\hline
\end{tabular}

${ }^{a}$ The averages for dummy variables serves as percentages; a mean of 0.93 means that 93 percent of the households are headed by male and only 7 percent are headed by female. Source: Field survey, 2008

Education of the household head, food self-sufficiency, and income from sources other than NTFPs significantly affect the amount of annual income earned from NTFPs by the households. Better educated household heads depend lesser on NTFP as a source of income. Similarly, higher the food self-sufficiency and higher the income from other sources, lesser is the dependence on NTFPs. Area of paddy-land owned also has a negative relation with the income earned from NTFP. Paddy-land is the most fertile category of land compared to upland and khoriya; thus paddyland contribute more to the crop production and thereby the food self-sufficiency of the household. Thus, household owning greater area of paddy-land depend lesser on NTFPs as a source of income.

The findings of the regression analysis reveal that NTFP trading is not an economically attractive income source for collectors for the current level of prices offered. Similar finding have been reported by other studies conducted in the mid-hills of Nepal (Bista and Webb, 2006; Babulo et al., 2008). The coefficients of regression implies that as long as a household is secure in terms of food self-sufficiency and has a higher annual income from alternative sources, they depend less on NTFP as a means of earning. This is because the labour involved in collection, cleaning, drying, sorting and carrying of NTFP from their settlements down to the market is not usually accounted for while setting the price of NTFPs. If the cost of family labour involved is deducted from the sale values of NTFP, the collectors actually have little or no profit margin. Despite this, collectors are still engaged in this activity in the absence of alternative income opportunities available locally. In a cash-constrained economy, even a small amount of earnings has a significant value as it helps to fulfil some subsistence requirements.

\footnotetext{
${ }^{1}$ LSU is aggregates of different types of livestock kept at household in standard unit calculated using the following equivalents; 1 adult buffalo $=1 \mathrm{LSU}, 1 \mathrm{cow}=0.8 \mathrm{LSU}, 1$ calf $=0.4 \mathrm{LSU}, 1$ pig $=0.3 \mathrm{LSU}, 1$ sheep or goat $=0.2$ LSU, and 1 poultry $=0.1 \mathrm{LSU}$.
} 
Table 3: Socio-economic Factors Affecting the Income Earned from NTFPs by a Household

\begin{tabular}{lccc}
\hline Explanatory variables & Coefficients & Std. Error & $\mathrm{p}$-value \\
\hline agehhh & -0.223 & 0.146 & 0.132 \\
sexhhh & 0.120 & 0.125 & 0.338 \\
eduhhh & $-0.267^{* *}$ & 0.128 & 0.043 \\
econactpop & 0.047 & 0.157 & 0.764 \\
paddyland & -0.069 & 0.135 & 0.610 \\
upland & 0.128 & 0.133 & 0.341 \\
foodsuff & $-0.232^{*}$ & 0.12 & 0.109 \\
incothers & $-0.579^{* * *}$ & 0.147 & 0.000 \\
Intercept & $1.30 \mathrm{E}-016$ & 0.115 & 1.000 \\
\hline
\end{tabular}

Excluded variables: khoriya, lsu; $F_{8,51}=2.86, p=0.01$, and $R$ square $=0.31$

${ }^{*},{ }^{* *},{ }^{* * *}$ means significant at 10 percent, 5 percent, and 1 percent respectively

Nevertheless, the demand for NTFPs is very high both in the national as well as in international markets. Besides, the altitude of Chepang settlements lies in the zone of maximum species richness of medicinal and aromatic plants. Thus, NTFPs can still be an important source of income generation for this community, but only if they can be offered better prices for the products they collect. For this, provision of primary processing and storage facilities, trainings, and capacity building for understanding the legal requirements of NTFP trade and bargaining power of the community is required. Studies have shown that bringing the households together in a group through community based institutions like cooperatives can help the communities to receive better prices for their products by empowering them and lending them a group voice for bargaining with the intermediaries (Edwards, 1996; Bista and Webb, 2006). The PCL is already a functional community based institution of the Chepang community which can be developed as a collection centre at the road-head. A short-term financial support for the $P C L$ and trainings to the staffs and members regarding the institutional management can have a significant effect on the bargaining power of the PCL and improve its competitiveness in the NTFP market. Development agencies need to empower the manpower in the PCL by providing trainings related to business and institutional management. If the profit margin of PCL can be improved, it will act as an important medium for the Chepang community in Shaktikhor and adjoining VDCs to extract higher benefits from the NTFP business.

\section{CONCLUSIONS AND RECOMMENDATIONS}

Chepangs live nearby the forest in the altitudinal ranges where the forests are very rich in biodiversity. There is a huge demand for NTFPs both in the national as well as in the international markets. Thus, marketing of commercially important NTFP can be a potential source of livelihoods for Chepang households. However, commercial exploitation of species like Kaulo, Daar, Kurilo, and Bajuri has led to the destructive harvesting of these species. This calls for a need of training to the collectors about the importance and methods of sustainable and scientific harvesting of such products. Further data analysis shows that marketing of NTFP is not very lucrative business for Chepang households who are relatively better off in terms of food self-sufficiency and higher household income from sources other than NTFPs. This is because, under the current situation, the price offered to the collectors is not profitable if the labour cost of collection, drying, sorting and bringing it down to the market is also accounted for. Still, more than 60 percent of the Chepang households covered by the study are involved in collecting and selling of NTFPs. This is because of the lack of alternative employment opportunities available locally in the Chepang settlements, and in a cash-constrained economy even small amount of cash earning is of great importance. In order to improve the profit margin of the Chepangs in Shaktikhor VDC, 
capacity building of the community in terms of technical trainings, preliminary processing, financial support, storage facilities, and knowledge of legal requirements can help to improve the bargaining power of the community. PCL is an already functional community based institution in Shaktikhor run by the Chepang community, and its members cum shareholders consist of Chepang households from Shaktikhor, Kaule, Korak and Siddi VDCs. $\mathrm{PCL}$ was established with the objective of improving the bargaining power of Chepangs in the NTFP marketing. PCL can provide institutional backup for the community and lend a group voice to bargain for better prices. PCL can also play a role in setting rules and regulations for sustainable harvesting of NTFPs that will contribute to stop the overextraction of resources. If the profit margin of PCL can be improved, it will act as an important medium for the Chepang community in Shaktikhor and adjoining VDCs to extract higher benefits from the NTFP business. However, PCL has to face tough competition with the road-head businessmen in Shaktikhor, and has been facing challenges in the NTFP trade due to lack of financial capital to buy NTFPs from the community. PCL needs financial, technical, and capacity development support from the development agencies for few more years before the Chepangs can take the institutional responsibilities solely by themselves. On the part of the government, promotion of sustainable NTFP business in the area by adoption of 'innovation policy' is recommendable. Adaptation research, extension, adult education, and sustainable institution are the important components of innovation policy. Possibilities of domestication of NTFPs, optimum harvesting age, harvesting time, and harvesting methods can be determined by NTFP related adaptation researches. The findings of the research can then be disseminated to the communities through trainings for which the staffs of the PCL can first be trained as the local resource persons, who in turn can extend the research findings at the household level. PCL can be promoted as the sustainable institutional components of innovation policy, since it is easier to strengthen an already existing institution rather than starting a new one. Finally, this study fails to gather data on the risks and costs borne by various agents along the market chain and selling price for agents further down the channel. A future study covering the associated costs and selling prices for all the agents in the channel, and calculation of marketing margin and profit margin distributed along the market chain is highly recommendable.

\section{REFERENCES}

Aryal, K., 2007. Uncultivated plants: An option for livelihood support of the people in mid-hills of Nepal. Unpublished master's thesis, Uppsala University, Swedish Biodiversity Centre, Sweden.

Babulo B., B. Muys, F. Nega, E. Tollens, J. Nyssen, J. Deckers and E. Mathijs, 2008. Household livelihood strategies and forest dependence in the highlands of Tigray, Northern Ethiopia. Agricultural Systems, 98: 147 - 155.

Belcher, B. M. 2005. Forest product markets, forests, and poverty reduction. International Forestry Review, 7(2): 82 - 89.

Bista, S. and E. Webb, 2006. Collection and marketing of non-timber forest products in the far western hills of Nepal. Environmental Conservation, 33(3): 244 - 255.

Chhetri, H.B. and V.N.P., Gupta, 2006. NTFP potential of upper Mustang - A trans-himalayan region in western Nepal. Scientific World, 4(4): 38 - 43.

Chupezi, T.J., O. Ndoye, M. Tchatat and B. Chikamai, 2009. Processing and marketing of non-wood forest products: Potential impacts and challenges in Africa. Discovery and Innovation, 21(1):60- 65.

Edwards, D.M., 1996. Non-Timber forest products from Nepal; Aspects of the trade in medicinal and aromatic plants. Kathmandu: Ministry of Forests and Survey Centre.

FAO, 2003. Harvesting of the non-wood forest products. Rome: Food and Agriculture Organization of the United Nations.

FORWARD, 2001. Formulation of a comprehensive praja development programme, Part II. Bharatpur: Forum for Rural Welfare and Agricultural Reform for Development. 
Fuashi, A.N., 2005. Production and marketing of non-timber forest products NTFPs, A major source of rural and national income in the south west province of Cameroon. Paper presented at the 17th Commonwealth Forestry Conference, Colombo, Sri Lanka. Retrieved October 10, 2010 from http: / /www.cfc2010.org/2005/CFC\%20pdfs/A\%20N\% 20Fuashi\%20paper.pdf

Gribnau, C., S. Pradhan, S. Rana, N.S. Chhetri and S. Ghimire, 1997. Can orange trees blossom on barren lands? (In Nepali). Kathmandu: Praja Community Development Programme.

Hodgson, B.H., 1874. On the Chepang and Kusunda tribes of Nepal. In: Essays on the Languages Literature and Religion of Nepal and Tibet. New Delhi: Manjusri Publishing House, pp. 45 - 54. http://www.un.org.np/maps/maps.php [Retrieved: May 27, 2008]

Kunwar, R.M. and R.W. Bussman, 2008. Ethnobotany in the Nepal Himalaya. Ethnobiology and Ethnomedicine, 4(24). Available at http://www.ethnobiomed.com/content/4/1/24. Jun. 10, 2009.

Kunwar, S. C., A. S. Ansari and H. Luintel, 2009. Non-timber Forest products enterprise development: regulatory challenges in the Koshi hills of Nepal. Journal of Forest and Livelihood, 8(2): 39 - 50.

Lacuna-Richman, C., 2004. Subsistence strategies of an indigenous minority in the Philippines: nonwood forest product use by the Tagbanua of Narra, Palawan. Economic Botany, 58(2): 266 - 285.

Maharjan, K.L. and A. Khatri-Chhetri, 2006. Role of forest in household food security: evidence from rural areas in Nepal. Annual Report of Research Centre for Regional Geography, 15: 41 - 67.

Maraseni, T.N., G.P. Shivakoti, G. Cockfield and A. Apan, 2006. Nepalese non-timber forest products: an analysis of the equitability of profit distribution across a supply chain to India. Small-scale Forest Economics, Management and Policy, 5(2): 191 - 206.

Neumann, R. P. and E. Hirsch, 2000. Commercialization of non-timber forest products: review and analysis of research. Bogor: Centre for International Forestry Research.

Pandit, B. H., 2008. Economics of non-timber forest production promotion and marketing: a case study from Malekhukhola Watershed of Dhading district, Nepal. The Initiation, 2: 145 - 156.

Pandit, B. H. and G. B. Thapa, 2003. A tragedy of non-timber forest resources in the mountain commons of Nepal. Environmental Conservation, 30(3): 283 - 292.

Piya, L., K. L. Maharjan and N. P. Joshi, 2011a. Forest and food security of indigenous people: a case of Chepangs in Nepal. Journal of International Development and Cooperation, 17(1): 113 - 135.

Piya, L., K. L. Maharjan and N. P. Joshi, 2011b. Livelihood strategies of indigenous nationalities in Nepal: a case of Chepangs. Journal of International Development and Cooperation, 17(2): 99 - 113.

Rai, N. K., 1985. People of the Stones: the Chepangs of Central Nepal. Kathmandu: Centre for Nepal and Asia Studies.

Rijal, A., 2008. Living knowledge of the healing plant: Ethno-phytotherapy in the Chepang communities from the mid-hills of Nepal. Ethnobiology and Ethnomedicine, 4(23). Retrieved June 10, 2009 from http: / /www.ethnobiomed.com/content/4/1/23

Sadashivappa, P., S. Suryaprakash and V. V. Krishna, 2006. Participation behaviour of indigenous people in non-timber forest products extraction and marketing in the dry deciduous forests of South India. Paper presented in the Conference on International Agricultural Research for Development, University of Bonn, October 11 - 13, 2006.

Sills, E. O., S. Lele, T. P. Holmes and S. K. Pattanayak, 2003. Non-timber forest products in the rural household economy, In: E. O. Sills and K. L. Abt (eds.), Forests in a Market Economy, Netherlands: Kluwer Academic Publishers, pp. 259 - 281.

Thapa Magar, D. B., 2008. Contribution of non-timber forest products in the livelihood of Chepang community. A Final Report Submitted to Social Inclusion Research Fund, SNV, Nepal.

WCFSD, 1999. Our Forests Our Future. Cambridge: Cambridge University Press, World Commission on Forests and Sustainable Development.

World Bank, 2001. A Revised Forest Strategy for the World Bank Group. World Bank, Washington D.C. 